\title{
Tales of a disabled woman working at ableist, sexist workplaces
}

\author{
Devyani Tewari ${ }^{1}$
}

Accepted: 26 September 2021 / Published online: 18 October 2021

(C) The Author(s), under exclusive licence to O.P. Jindal Global University (JGU) 2021

\begin{abstract}
To me, personal is theoretical as well as political. Therefore, when exploring the question of how the workplace is an ableist as well as a sexist space for disabled women, I have linked theory to my lived experiences. My experiences are the starting point for my explication of how intersectional feminist theories on disability, spatial practices, silence, violence, and discrimination provide a source of strength, action, voice, language, and a name to experiences of disabled women of colour working in sexist and ableist workplaces. Relying upon intersectionality, I propose that disabled women are more vulnerable to sexual harassment at the workplace. I have drawn upon Sara Ahmed's work on 'girling' and 'gender fatalism' to propose concepts of 'disabling' and 'disability fatalism'. I conclude my feminist resistance project by asserting the necessity of intersectional feminist workplaces.
\end{abstract}

Keywords Disability · Gender · Intersectional feminism · Workplace · Violence

\section{Introduction}

'...thinking is periodically nudged, frightened, inspired, or terrorised into action by strange encounters.' ${ }^{1}$

As a 13-year-old girl in India, I was diagnosed with epilepsy. Maybe one already knows this, but workplaces are not the kindest worlds to persons with disabilities, especially women with invisible disabilities. Years later as a law student and as a legal professional at different workplaces, I could sense wrongs. Workplaces are meant to accommodate only certain bodies. When you are in places where you are

\footnotetext{
1 William Eugene Connolly, Neuropolitics: Thinking, Culture, Speed (1st edn, University of Minnesota Press 2002) 94.

Devyani Tewari

devyanitewari@uvic.ca

1 O P Jindal Global University, Sonipat, India
} 
not expected to be, you have different experiences ${ }^{2}$ from the rest of your peer group. It takes you years to pinpoint the wrongs you felt as instruments of ableism, racism, and sexism.

Disability is never the norm or the dominant narrative in legal education, it is always the 'other'. When we study disability, we seldom study it from the standpoint of disabled women, one of the reasons being, their rare visibility in public spaces. Spatial practices in our society are constituted and preserved in a way so as to preserve gendered and ableist identities and spaces. ${ }^{3}$ Consequently, disabled women are shunned from the ableist gendered workplace towards home, thus impairing their ability to constitute knowledge by sharing their truths publicly.

In this paper, I make sense of my uncomfortable and strange encounters by exploring the question of how the workplace is an ableist as well as a sexist space for disabled women. My personal experiences or rather my strange encounters in my everyday world have left me feeling silenced, unprotected, and more vulnerable. Dorothy Smith lays emphasis on treating the everyday world as problematic, a world in which questions about social organisation and social relations arise. ${ }^{4}$ Our actions and experiences are organised by social relations beyond our control. ${ }^{5}$ My encounters made me reflect upon the linkages between my social status and social relations in this everyday world of which the workplace is a significant part.

I engage with the question of the workplace being ableist as well as sexist by adopting an autoethnographic approach whilst delving into feminist analyses on intersectional discrimination and violence. My body and experiences serve as a site to critically examine the discrimination against disabled women at workplaces within the feminist theoretical framework. Section 2 discusses my experiences in the problematic everyday world. In Sect. 3, I make sense of my experiences by engaging with Rosemarie Garland-Thomson's feminist disability theory, ${ }^{6}$ Sara Ahmed's intersectional feminist theory on spatial practices, ${ }^{7}$ Audre Lorde's account on silence and the relationship between the theory of intersectionality, ${ }^{8}$ on one hand, and discrimination and violence, on the other hand, as propounded by Kimberlé Crenshaw, ${ }^{9}$ and further developed by Patricia Hill Collins. ${ }^{10}$

\footnotetext{
2 Sara Ahmed, Living a Feminist Life (1st edn, Duke University Press 2016) 10.

3 See Rebecca Johnson, 'Law and the Leaky Woman: The Saloon, the Liquor Licence, and Narratives of Containment' (2005) 19(2) Continuum 181; Rebecca Johnson, 'Blurred Boundaries: A Double-Voiced Dialogue on Regulatory Regimes and Embodied Space' (2005) 9 Law Text Culture 157.

${ }^{4}$ Dorothy E Smith, The Everyday World as Problematic: A Feminist Sociology (1st edn, Northeastern University Press 1987) 91.

5 Ibid. 92.

6 See Rosemarie Garland-Thomson, 'Misfits: A Feminist Materialist Disability Concept' (2011) 26(3) Hypatia 591, Rosemarie Garland-Thomson, 'The Story of My Work: How I Became Disabled' (2014) 34(2) Disability Studies Quarterly .

7 Ahmed, Living a Feminist Life (n 2).

8 Audre Lorde, Sister Outsider: Essays and Speeches (1st edn, Crossing Press 1984).

9 Kimberlé Crenshaw, 'Demarginalizing the Intersection of Race and Sex: A Black Feminist Critique of Antidiscrimination Doctrine, Feminist Theory and Antiracist Politics' 1989(1) University of Chicago Legal Forum 139.

10 Patricia Hill Collins, Intersectionality as Critical Social Theory (1st edn, Duke University Press 2019) 237. The article does not venture into the realm of critiquing or reforming the law. In writing this article, I wanted to stay as close as possible to the problematic everyday world. Since the article is an intersec-
} 
Intersectionality is not the sole theoretical framework to assess and analyse the issue discussed herein. However, I am relying upon intersectionality because, unlike previous works which were rooted in white experiences, Crenshaw's theoretical framework of intersectionality carefully analyses the impact race has when studying patriarchy, violence, discrimination, separate spheres, etc. ${ }^{11}$ Similarly, in my view, intersectionality aids in analysing violence and discrimination based on gender and disability when the voice analysing the issue is that of a disabled woman of colour.

\section{My body, my experiences}

The first rule I learnt as a young teenager with a disability was non-disclosure of disability to anyone. I was told that this cloak of secrecy was only to protect me from any stigma that may come to be associated with me. At school, I soon learnt that the stigma was a reality when I overheard a few of my male classmates mocking persons with mental health problems and neurological issues. Nobody reprimanded them. When I went to law school, I thought things would be different, but they were not. When I sought out reasonable adjustments for the adverse effect of campus accommodation on my disability, the hostel warden paid no heed to it. Worse, I was branded a liar by few students because I was unable to obtain any reasonable accommodation. They thought that I did not have any medical condition which is why reasonable adjustments were not made. So, I had to live with two stigmas-my disability and my newfound reputation. Some who believed that I indeed had a disability, fetishised my disability.

Once I graduated law school and assumed the position of an in-house counsel at a famous corporation, I thought that I am not going to experience any more discrimination at the workplace. After all, I was aware of the Persons with Disabilities Act 1995, ${ }^{12}$ (now the Rights of Persons with Disabilities Act, 2016). ${ }^{13}$ Also, one of my tasks involved spreading awareness about the Sexual Harassment of Women at Workplace (Prevention, Prohibition and Redressal) Act $2013^{14}$ among the employees. However, now looking back I find myself to be too naïve. An alternative to my naivete could be the inability of the language of rights in the statutes to dismantle the sexist and ableist workplace I was in.

During the induction phase, I was notified that epilepsy was one of the medical conditions an employee could not have. I was stunned. It contravened the law and my human rights. If I told the examining doctor the truth, my services would be terminated for no fault of mine. So, I decided to lie. It seemed pragmatic and the only

\footnotetext{
Footnote 10 (continued)

tional feminist resistance project, I have tried to draw upon works of feminists of colour and disabled feminists to the utmost extent possible.

11 Crenshaw, 'Demarginalizing the Intersection of Race and Sex' (n 9) 154.

12 The Persons with Disabilities (Equal Opportunities, Protection of Rights and Full Participation) Act 1995, Act No. 1 of 1996.

13 The Rights of Persons with Disabilities Act 2016, Act No. 49 of 2016.

14 The Sexual Harassment of Women at Workplace (Prevention, Prohibition and Redressal) Act 2013, Act No. 14 of 2013.
} 
way to save my job. However, my conscience suffered and my journey of feeling guilty for something that is beyond my control began.

Next, I learnt what it meant to be a woman in a workplace. Sure, I had known this my whole life-lewd glances, ogling, sexist remarks on my achievement. But what I was to experience soon led to shame and ironically, guilt. My mentor at the corporation I was employed in, sexually harassed me. He was one of the members of the top management and had helped me with all the problems that I had faced, including problems equating to sexual harassment. Naturally, my trust and faith in humanity exploded when he started molesting and sexually harassing me towards the end of my tenure. Even after I left my job to start life afresh, his advances did not cease. He kept harassing me by calling me up regularly. My story coincided with the news headlines on sexual harassment of female law students by members of the senior judiciary. Nobody believed the young students, who will believe me? Everyone at my workplace thought that girls not dressing 'appropriately' (read: Western apparel) were seductresses and deserved to be harassed. Worse, my career would be ruined. I decided to stay mum. I was a feminist sensitising my co-workers on sexual harassment at the workplace but chose not to report it. Was I a failing feminist?

I had already proven to be complicit in ableism and antifeminism by not questioning the ableist policies and not reporting the sexual harassment. I had buried the guilt. To my horror, it resurfaced again. When I was sexually harassed once again at a different workplace, I reported the harassment. Although no action was taken against the harasser, the harassment stopped. Maybe it was the inaction on part of the top brass or the harassment itself or the fact that my sexual harasser was roaming freely that I got triggered again and broke down. In an unhealthy work environment where there was little support for me and my story of sexual harassment, my mental and physical health suffered. I kept thinking — did I even have a right to space as a feminist woman in a patriarchal work environment? Why was I being harassed again? I had done nothing to deserve it time and again. I did not want to see my harasser, so I shifted to a different floor where I would not see him. On the other hand, he sat comfortably in his chair and did not leave the floor he occupied. It seemed as if I was in the wrong.

I was fragile but felt proud that at least the harassment stopped and anyway I was moving to a different workplace. Things did look better in the new workplace but soon the shiny veneer wore off. My former employer had provided me with shared accommodation. However, I found myself in a toxic rooming situation. I had communicated my disability and other medical conditions, but it seemed that my housemates took only perfunctory consideration of that. Upon introspection, I realised there was no duty of reasonable accommodation on my housemates. If they respected my disability, I should be grateful to them. If they did not, which was most of the time, I needed to find a solution. I knew that they could intimate my employer about my disability. I had read a lot about the termination of services of competent persons with epilepsy. Since there was no respect for my boundaries and the housing situation was affecting my health, an angst-ridden despondent version of myself silently moved out. This was the third time that I was surrendering my personal space. I was compunctious of guilt for not fighting for my personal space in my first workplace. I was not feeling guilty unlike the first time I was harassed 
but the consequences were not any different. Every time I was harassed, the harasser was irreproachable while I was pilloried by the harassers and their friends for my actions. I was eventually bereft of my space. Why did this happen each time? Ideally, the contrary should happen. So, the problem either lay with my body or the world. It was inevitable that the spatial practices of the antifeminist ableist world would discriminate against me. My body was the site of ableist and/or sexist harassment as well as the site of protest. However, the protest was falling on deaf ears although the voice protesting was not timorous.

In my former workplace, some of the disabled colleagues requested reasonable accommodation with respect to participation in the formulation of the timetable. Anticonvulsants, antidepressants, and medicines of similar nature can affect sleep and make the instructor miss their early morning classes. In the time of COVID-19 when mental health issues were the new pandemic, it was even more necessary to consider this request. I had taught students who displayed little to no sensitivity on disability rights and one of our requests was sensitisation of administrative staff and students on disability rights. This would have prevented an unhealthy housing situation as well as enabled the workplace to be a safe space for disabled employees. Nevertheless, no heed was paid to these requests which flouted the Rights of Persons with Disabilities Act 2016. ${ }^{15}$ Was the language of rights not adequate because my protests failed constantly? It was time to critically analyse my vulnerabilities, introspect into my silences, and look at the world around me-the world that was not built for me.

\section{Silence and vulnerabilities vis $a$ vis the ableist sexist world}

This section analyses my experiences in light of feminist theory on spatial practices and discrimination against multiply-disadvantaged women. The first sub-section pertains to exploring and challenging the world that is built to accommodate only certain bodies. The second sub-section discusses Kimberlé Crenshaw's theory of intersectionality and its applicability to discrimination against disabled women. The third sub-section delves into Patricia Hill Collins' proposition on the linkages between violence and systems of power or oppression. I have centred my story while navigating various feminist perspectives.

\subsection{Reflections on navigating an antifeminist ableist world}

According to Ahmed, 'a norm is something that can be inhabited', something in which bodies can reside. ${ }^{16}$ Therefore, the experience of not (or being incapable of) inhabiting a norm, can be treated as not living so easily where one resides. ${ }^{17}$

\footnotetext{
15 See Rights of Persons with Disabilities Act s 2(h), 21; Rights of Persons with Disabilities Rules 2017 Section 3.

16 Ahmed, Living a Feminist Life (n 2) 115.

17 Ibid.
} 
You might be asked questions; you might be made to feel questionable, so that you come to feel that you do not belong in the places you live, the places you experience as home; you might turn up and not be allowed in or find it too uncomfortable to stay. Norms are often maintained through how those who do not quite inhabit norms are treated. ${ }^{18}$

Norms can be created by institutions, in the form of policies, regulations or arrangements. ${ }^{19}$ Norms are also at play in the everyday world in which bodies are moving. ${ }^{20}$ Questionable existence is often about passing: in order to pass within (an organisation, an area, etc), an individual has to pass as something he/she/they are considered not to be. ${ }^{21}$ Individuals who do not inhabit a norm are asked to account for themselves. ${ }^{22}$ When giving an account of themselves, they can feel that they have to account for themselves. ${ }^{23}$ Questionable existence in a sense can feel like a residence, resulting in the individual feeling like not being where they are at. ${ }^{24}$ Questions can also be like assertions. When an individual is asked to explain their presence, the question is a way of being asserted that the individual does not belong here. $^{25}$

Whenever I requested reasonable accommodation on grounds of disability, be it as a college student or an employee, I had to explain myself. The explanation was not limited to legalese or medical knowledge about reasonable adjustments vis a vis epilepsy. To give an explanation encompassed the account of how I ended up being disabled, how my body is different from those who question me. When I reported sexual harassment, the questioning session was not restricted to the actions and/or words of the harasser. The questions made me explain how I could be seated in my place working diligently on my lectures when my harasser was roaming in my vicinity, confidently making advances at me. My being was in question, not his. To borrow from Simone de Beauvoir, the right to question me and my obligation to explain my very being render me 'the Other', who does not deserve to be at the organisation while those who have the right to question me are 'the Absolute'. ${ }^{26}$ They are entitled to be there. My body is the ultimate question mark. ${ }^{27}$

My disabled body invited derision and stigma since I was in school. Why? Erving Goffman explains the concept of stigma attached to bodies of disabled persons. ${ }^{28}$ My body is stigmatised, because it is different in an undesired manner from what the

\footnotetext{
18 Ibid.

19 Ibid.

20 Ibid.

21 Ibid.

22 Ibid. 116.

23 Ibid.

24 Ibid.

25 Ibid. 117.

26 See Simone de Beauvoir, The Second Sex (first published 1953, Everyman's Library 1993) xliv-xlv.

27 Ahmed, Living a Feminist Life (n 2) 117.

28 Erving Goffman, 'Selections from Stigma' in Lennard J Davis (ed), The Disability Studies Reader (Routledge 2006) 132.
} 
'normals' had expected. ${ }^{29}$ According to him, 'normals' are those whose appearance is in consonance with the specific societal expectations. ${ }^{30}$ 'Normals' believe that the stigmatised individual, such as me, is not fully human. ${ }^{31}$ Based on this belief they discriminate against the disabled individuals in varied ways and develop a stigmatheory, an ideology to account for the inferiority of the disabled individual. ${ }^{32}$ The stigma-theory gives an explanation for an antipathy based on bodily differences. ${ }^{33}$ 'Normals' use specific stigma terms like cripple, moron, in their everyday discourse without thinking about the original meaning of these terms. ${ }^{34}$ Stigma affected my ability to sit comfortably in my chair at the workplace and live peacefully in my old accommodation. Meanwhile 'normals' moved freely and comfortably occupied their seats.

Some individuals can move around freely because they seem to inhabit the norm in the sense that their appearance is consistent with an expectation of who truly belongs to a place (a street, neighbourhood, an organisation). ${ }^{35}$ Sexual harassment at workplace is a speech, gesture and/or action that questions women's existence at workplaces. Sexual harassment hinders women from enjoying mobility which is a male privilege. When I was sexually harassed, I was told that I did not belong in the workplace. Sexual harassment showed me my place in space, it told me what my social position is. ${ }^{36}$ It made me a woman, curtailed my mobility, and rendered me subordinate to men. ${ }^{37}$ Similarly, a callous attitude towards reasonable accommodation and/or derision directed at my disability are means of subordination. They are tacit ways of telling me that I do not belong in the workplace.

To pass through unquestioned often requires passing as someone inhabiting the norm. ${ }^{38}$ This is why I decided to act non-disabled for a long time. I did not disclose that I had epilepsy as my former employer would have terminated my services regardless of my merit. Acting non-disabled meant not being questioned.

Since I did not inhabit existing norms, I experienced (and still experience) discomfort. ${ }^{39}$ 'Comfort is about the fit between the human body and object'; ${ }^{40}$ an encounter between more than one body. ${ }^{41}$ To non-disabled bodies, the workplaces I inhabited are comfortable spaces because they allow non-disabled bodies to fit in. ${ }^{42}$ Social spaces like the workplace are similar to the surfaces of pieces of furniture

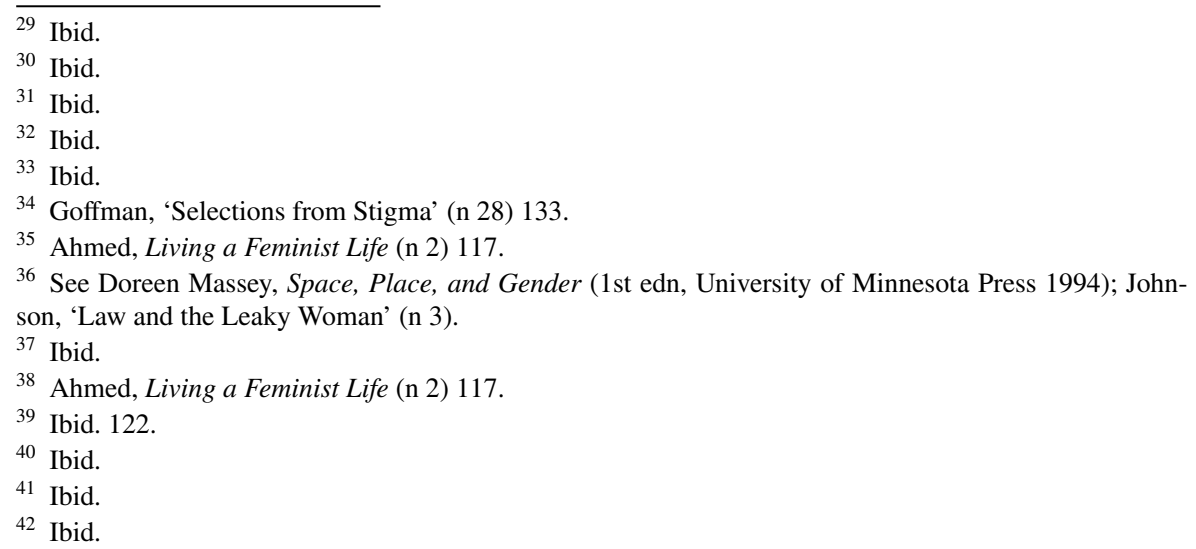


(for instance, sofas, beds, and chairs) which acquire their shape by the impression of some bodies inhabiting it. ${ }^{43}$ Since my body is that of a disabled woman of colour, I do not fit in these pieces of furniture. My body gets sexually objectified, sometimes racially fetishised as that of a subservient Asian woman. Objectification and racial fetishisation treat my body as a site of erotic pleasure. I get sexually harassed. Racism operates to make me desired and banished simultaneously. Disclosure of disability makes me more vulnerable and ironically more visible than earlier. ${ }^{44}$ I do not have the right body because the right body may be fully functioning; it is an able body. $^{45}$

When we have uncomfortable experiences, we start thinking differently about the world. Garland-Thomson uses the terms 'misfit' and 'misfitting' to underline the dynamic material relation between body and world that makes disability. ${ }^{46} \mathrm{~A}$ fit takes place when a harmonious, suitable interaction happens between a 'particularly shaped and functioning body and an environment that sustains that body'. ${ }^{47} \mathrm{~A}$ misfit ensues when the surrounding environs do not support the body that encounters them. ${ }^{48}$ The physical and social spaces through which we navigate our lives have a tendency to fit the needs of majority bodies and leave behind others, like people with disabilities as misfits. ${ }^{49}$ We become disabled when we experience the notion of misfitting. ${ }^{50}$ The concept of misfitting explains our exclusion from social and material institutions. ${ }^{51}$ It is the social order which is disabling, not the body. ${ }^{52}$ 'I became disabled, then, similarly to the way I had become a woman. ${ }^{53}$

'Although woman was an identity I had always claimed and which had claimed me, disabled was an identity, from which I fled. ${ }^{54}$ Why did I flee? Because I was afraid of the stigma that accompanied my disability. That stigma rendered me visible and defenceless. So, I stayed silent, but my silences did not protect me. ${ }^{55}$ I stayed silent as a 13-year-old schoolgirl when my classmates disparaged me. I stayed silent as a 29-year-old legal professional caught in an anguish-wrought housing situation where I could not speak up for my housing needs. Lastly, I stayed silent when other

\footnotetext{
43 Ibid. 123.

44 Graham Thornicroft, Shunned: Discrimination Against People with Mental Illness (1st edn, Oxford University Press 2006) 180. (Comprehensive academic literature has reported the large amount of stigma accompanying mental impairments and the impediment this poses to disclosure).

45 Ahmed, Living a Feminist Life (n 2) 124.

46 Garland-Thomson, 'Misfits' (n 6).

47 Garland-Thomson, 'The Story of My Work' (n 6). (A sustaining environment is a material context of received and built things ranging from accessibly-designed public spaces, welcoming natural surroundings, communication devices, tools, and implements, as well as other people).

48 Ibid.

49 Ibid.

50 Ibid.

51 Ibid.

52 Ibid.

53 Ibid.

54 Ibid.

55 Lorde, Sister Outsider (n 8).
} 
disabled colleagues and I did not receive any word from the management on reasonable accommodation.

Why am I speaking up now? Am I not afraid anymore? Of course, I am afraid, because the fear of stigma, humiliation, judgment, censure, and contempt has not ceased. More importantly, the path of 'transformation of silence into language and action is an act; of self-revelation' ${ }^{56}$ and that always seems beset with danger. ${ }^{57}$ But I have learnt that I will never really be my true whole self if I stay silent because there is always a part of me that wants to be spoken out. ${ }^{58}$ To survive in ableist sexist workplaces, multiply-disadvantaged women had to learn their most vital lesson-that our survival was never intended. ${ }^{59}$ As a multiply-disadvantaged woman, I have learnt this lesson because I do not inhabit the norm. However, I, like many others in my position, have been socialised to respect fear more than my requirements for language and definition. ${ }^{60}$ Nevertheless, I need to break that silence because silence is one of the several uncomfortable experiences emanating from misfitting in unsustainable environments. Silence immobilises me, ${ }^{61}$ it genders and disables me. I finally found the strength to understand my strange encounters and challenge the world where I misfit by studying intersectional feminist theory.

\subsection{Exploring intersectionality and its relationship with discrimination}

Had I not been disabled, my pitfalls and vulnerabilities would have lessened. ${ }^{62}$ Sex, race, class, and disability are real differences. ${ }^{63}$ I could never ignore the differences separating me from my non-disabled self and/or my harassers, making me more vulnerable to harassment. ${ }^{64}$ It is intersectionality that makes me ponder over my vision of a sustainable environment-a feminist workplace that does not disable me. The fact that I experience dual burdens and the social stigma around disability, somewhere affected my silent subordination to harassment and harassers. However, no good comes out of silence as my silence was construed to mean inferiority and submissiveness to class-privileged male ableist dominance. I was oppressed not only as a woman but also as a disabled individual.

A theoretical framework considering intersectionality can sufficiently address the unique discrimination and subordination faced by multiply-disadvantaged women ${ }^{65}$ like me. This is because multiply-disadvantaged women experience discrimination from discrete sources ${ }^{66}$ such as gender, disability, race, etc. To exemplify, disabled

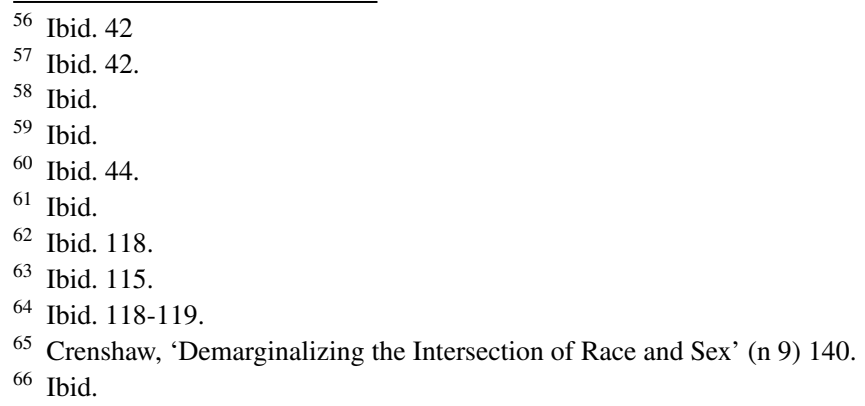


women at workplaces can be discriminated against either by non-provision of reasonable accommodation or sexual harassment.

To explain the intersectional discrimination resulting from gender and race hierarchies, Crenshaw provides the metaphor of a 'basement which contains all people who are disadvantaged on the basis of race, sex, class, sexual preference, age and/or physical ability. ${ }^{67}$ She explains:

These people are stacked-feet standing on shoulders-with those on the bottom being disadvantaged by the full array of factors, up to the very top, where the heads of all those disadvantaged by a singular factor brush up against the ceiling. Their ceiling is actually the floor above which only those who are not disadvantaged in any way reside. A hatch is developed through which those placed immediately below can crawl. Yet this hatch is generally available only to those who-due to the singularity of their burden and their otherwise privileged position relative to those below-are in the position to crawl through. Those who are multiply-burdened are generally left below.... ${ }^{68}$

This metaphor exemplifies the conditions of women, ${ }^{69}$ and how women are differently situated in relation to each other. Just below the ceiling, lie women who, but for their sex, are equal to men. This group comprises white heterosexual middle-class or upper-class non-disabled women. Towards the bottom of the basement, lie lower-class lower-caste disabled trans or queer women of colour belonging to a religious minority. I, as a disabled heterosexual upper-caste middle-class immigrant cis-gendered woman of colour, lie somewhere in the middle of the basement. Relying upon the theoretical framework of intersectionality, I argue that multiplyburdened women face a higher likelihood of being subjected to sexual harassment at the workplace. ${ }^{70}$

Using the theory of intersectionality, Crenshaw investigates gender-based violence and considers how the experiences of women of colour are normally the product of intersecting patterns of racism and sexism. ${ }^{71}$ Intersection of patterns of subordination is evident in the sexual harassment experiences of black women who are disadvantaged on account of race and gender. ${ }^{72}$ Black women are located within at least two systems of oppression: racism and sexism. ${ }^{73}$ This dual vulnerability does not simply imply that their disadvantages are multiplied; rather, it means, that the patterns of racism and sexism intersect in their lives resulting in distinctive

\footnotetext{
67 Ibid. 151.

68 Ibid. 151-152.

69 Shreya Atrey, 'Women's Human Rights: From Progress to Transformation, An Intersectional Response to Martha Nussbaum' (2018) 40(4) Human Rights Quarterly 859, 860.

70 See Purna Sen and Rosario Grima Algora, Sexual Harassment against Women with Disabilities in the World of Work and on Campus (UN Women 2020).

71 Kimberlé Crenshaw, 'Mapping the Margins: Intersectionality, Identity Politics, and Violence against Women of Colour' (1991) 43(6) Stanford Law Review 1241, 1243.

72 Kimberlé Crenshaw, 'Race, Gender, and Sexual Harassment' (1992) 65 Southern California Law Review 1467.

73 Ibid. 1468.
} 
experiences. $^{74}$ Widespread insidious assumptions about Black women have an impact on the forms of sexual harassment that Black women face, as well as whether or not their accounts will be considered true. ${ }^{75}$ In the words of Crenshaw, 'Intersectional subordination need not be intentionally produced; in fact, it is frequently the consequence of the imposition of one burden that interacts with pre-existing vulnerabilities to create yet another dimension of disempowerment. ${ }^{\text {, }}{ }^{2}$

Sexual harassment at workplace against disabled women is one such manifestation of intersectional subordination. Crenshaw's analyses can be expanded to examine disabled women's experiences of sexual harassment. Disabled women face a higher risk of violence than non-disabled individuals and men with a disability, considering the social, historical, and economic-based marginalisation and oppression of women with a disability. ${ }^{77}$ Their marginalisation affects their voice and 'equal participation in everyday life', ${ }^{78}$ which creates 'a vicious circle of cultural and economic subordination. ${ }^{, 79}$ Like Black women, pervasive stereotypes about disabled women's sexual behaviours are ubiquitous which affects reporting and adjudication of sexual harassment at workplace. ${ }^{80}$

While reading Crenshaw, I had my story at the back of my mind. I constantly interpret my story using her analyses. My non-disabled, sex-privileged, upper-class harassers lived above the ceiling while I could not even access the hatch without pulling myself 'into the groups that are permitted to squeeze through the hatch., ${ }^{81}$ My experiences of sexism were shaped by my disability and vice-versa. I did not report sexual harassment for the first time because my harasser assumed the high echelons of the institution which had equated epilepsy to a felony record. I knew that if I dared to report it, I would not be believed. My character as well as my conduct will be questioned. During induction, I had submitted certain medical test reports which if carefully scrutinised could be inferred to point to an underlying neurological condition. I did not want the cat to come out of the bag. And for what-I knew the harasser would go scot-free. I would be the one on trial. I would not be free. Two systems of power- ableism and sexism would finally choke me. The social system

\footnotetext{
74 Ibid.

75 Ibid. 1470.

76 Crenshaw, 'Mapping the Margins' (n 71) 1249.

77 Jennifer M Mays, 'Feminist Disability Theory: Domestic Violence Against Women with a Disability' (2007) 21 Disability \& Society 147, 151; Lesley Chenoweth, 'Invisible Acts: Violence Against Women with Disabilities' (1993) 2 Australian Disability Review 22; Lesley Chenoweth, 'Violence and Women with Disabilities: Silence and Paradox' (1996) 2(4) Violence Against Women 391.

78 Nancy Fraser, 'From Redistribution to Recognition? Dilemmas of Justice in a "Post-Socialist" Age' (1995) 212 New Left Review 68, 79.

79 Ibid.

80 See Sen and Algora, Sexual Harassment against Women with Disabilities in the World of Work and on Campus (n 70); Human Rights Watch, Invisible Victims of Sexual Violence:

Access to Justice for Women and Girls with Disabilities in India (HRW 2018). https://www.hrw.org/ report/2018/04/03/invisible-victims-sexual-violence/access-justice-women-and-girls-disabilities. Accessed 7 July 2021.

81 Crenshaw, 'Demarginalizing the Intersection of Race and Sex' (n 9) 152.
} 
did not support me. I was not a feminist at work because I feared more violence. I experienced (and still experience) gender and disability as violence.

\subsection{Violence vis a vis intersectionality}

Research has found that a bi-directional relationship exists between sexual violence and mental health problems. Women who have experienced sexual violence tend to develop acute mental health problems and those with severe mental health problems remain exposed to sexual violence. ${ }^{82}$ This is particularly significant because the boundary between disability and non-disability is blurred and constantly shifting. Someone who is not disabled can become disabled at any given moment. When disability interacts with pre-existing vulnerabilities like gender, intersectional subordination ensues. Therefore, women developing mental health problems as a result of sexual harassment become even more vulnerable to patriarchal ableist domination than they were previously.

Across varying social contexts, the use or threat of violence has been crucial to power relations that create disparities in society, such as sexual harassment within sexism. ${ }^{83}$ Therefore, violence as a saturated site is important-it shows how violence preserves different systems of power and the visibility of points of convergence of intersecting power relations ${ }^{84}$-in my case the intersections of gender and disability. Hill Collins explores how violence may serve as a navigational tool for examining intersectionality's main theoretical premise that 'systems of power mutually construct one another'. ${ }^{85}$ In other words, focusing on violence helps to understand the workings of racism, and heteropatriarchy as distinct systems of power as well as how violence constitutes a common thread that unites them together. ${ }^{86}$ Hill Collins explains:

Treating violence as a saturated site of power relations wherein the workings of power within and across capitalism, colonialism, racism, and heteropatriarchy are especially visible provides an entry point into theorizing intersecting systems of power. Saturated sites bundle together practices, social institutions, representations, and patterns of everyday social interaction that appear and reappear across seemingly separate systems of oppression. ${ }^{87}$

I propose that Hill Collins' propositions can be expanded to include ableism as a system of power. In looking at narratives of sexually harassed disabled women from the perspective of intersectionality, we can discern the distinctive systems of power of ableism and sexism. Sexual harassment against disabled women can be

\footnotetext{
82 Rashmi Rai and Ambarish Kumar Rai, 'Sexual Violence and Poor Mental Health of Women: An Exploratory Study of Uttar Pradesh, India' (2020) 8 Clinical Epidemiology and Global Health 194.

${ }^{83}$ Hill Collins, Intersectionality as Critical Social Theory (n 10) 237.

84 Ibid 237-238.

85 Ibid 237.

86 Ibid.

87 Ibid. 238.
} 
seen as a saturated site of power relations that unites and preserves the two separate systems of power or oppression, namely ableism and sexism. It is significant to note that in our ableist patriarchal society, workplace can also serve as a saturated site because it unites various modes of ableist patriarchal representations, practices, and patterns of social interactions that discriminate against women with disabilities. These representations and social interactions are ingrained with social practices that are necessary for the preservation of two distinct systems of power-sexism as well as ableism. It is the workplace where gendering (in my case-'girling') takes place. The rules of 'girling' are enacted in a mode of address. ${ }^{88}$ 'Violence is also a mode of address. ${ }^{89}$ Being a girl is a way of being taught what it is to have a body: you are told that you will be subjected to sexual violence and if you refuse to modify your behaviour in accordance with what the sexist society and your harasser's desire, then you can be made responsible for the violence directed toward you. ${ }^{90}$ That is the sad truth of gender fatalism. ${ }^{91}$ I was taught at a young age that my clothes were responsible for me being sexually harassed. People told me that I was too kind or too friendly with my harassers. I was slut-shamed, victim-shamed. They sexually harassed me because of something I did, something I wore, something that was inherent in me. I was policed unlike them.

Similar to the rules of girling, there are rules indoctrinated in disabled women like me. I call these rules 'disabling' as it is not disability that disables me but these rules that disable me. The rules shush me, tell me to not disclose my disability, not protest against people and/or institutions which do not accommodate me, direct me to modify my behaviour as to what the institutions and/or people desire inevitably implying that I must accommodate those who continue to preserve their norms by not accommodating bodies like me. Disability fatalism occurs when a disabled individual is made responsible for the discrimination meted out to him/her/them. The scornful laugh that I heard when I was 13, the rule prescribing epilepsy as a ground for termination of services, lack of reasonable accommodation for disabled students, all the malicious gossip about my disability over the ages, callous disregard of needs of disabled employees at the workplace by the employer and co-workers are nothing but discriminatory. They violate my personhood. However, disabled individuals like me are told that because we do not have the same body as that of our aggressors, we are to be blamed for what befalls upon us. I ask myself: how does one break out of this antifeminist ableist world of dominance?

Theorising violence as a 'saturated site of intersecting power relations' 92 underscores the importance of apparently individual and distinctive acts of resistance because it shows how notions and actions of resistance are themselves interlinked. ${ }^{93}$

\footnotetext{
88 Ahmed, Living a Feminist Life (n 2) 26 (Ahmed's usage of the word 'girling' denotes how gendering is enacted for girls).

89 Ibid.

90 Ibid.

91 Ibid.

92 Hill Collins, Intersectionality as Critical Social Theory (n 10) 240.

93 Ibid.
} 
An intersectional analysis that concentrates on domination encapsulates the instabilities and intricacies that illustrate how violence and anti-violence coexist. ${ }^{94}$ Therefore, individual resistance to sexual harassment by a disabled woman is likely to demonstrate the intersection between the two separate systems of power- ableism and sexism.

Penning down this piece makes me feel good about myself because it feels like an act of feminist resistance against patriarchy and ableism. While teaching and speaking at conferences I use my particulars to challenge the universal. ${ }^{95}$ For so long I have been obeying the norms formulated by patriarchal ableist workplaces that I eventually became silently subordinate to all my harassers. I finally snapped. When a feminist snaps, a feminist movement is waiting to happen because she has finally recognised the linkages between power relations, gender, and gender as violence. ${ }^{96}$ Now I want to resist any kind of domination inflicted upon my body-body of a disabled woman. I want to tell my truths and support the truths of other disabled women and create feminist norms and dwellings which people like me can inhabit. I want to have a more equal relationships with people who comfortably inhabit institutions. I want to live a feminist life. Intersectional feminism is as much present in my resistance as ableist antifeminism is present in the violence.

\section{Conclusion}

'What are the tyrannies you swallow day by day and attempt to make your own, until you will sicken and die of them, still in silence?' 97

Inequities prevail in the workplace between various sets of employees, but inequities are graver when the population is more vulnerable. ${ }^{98}$ Intersectionality helps in making sense of one's experiences when someone is more vulnerable than the rest of the workforce. My social status is inferior to others because of my gender and disability. Social status is intricately connected to social relations which explains my unequal relationships with others at the workplace — others who are expected to belong at the workplace.

All my strange encounters had the same ending, that of me surrendering my space because questions were raised at my existence, my very being, my very presence at the workplace. I was (and still am) 'the Other'. I did not belong at the workplace. However, I want to reclaim my disabled identity, speak up and break the silence about the tyrannies that I have endured silently. My body is not wrong, I had become disabled because of misfitting in unsustainable environments. What are disabling are the norms that organisations have in place so as to keep out bodies like me as well as the ableist ideas that are inculcated in young disabled girls like me.

\footnotetext{
94 Ibid.

95 Ahmed, Living a Feminist Life (n 2) 10.

96 Ibid. 3.

97 Lorde, Sister Outsider (n 8).

98 Shreya Atrey, 'Introduction: Intersectionality from Equality to Human Rights' in Shreya Atrey and Peter Dunne (eds), Intersectionality and Human Rights Law (Oxford: Hart Publishing 2020) 2.
} 
I propose that multiply-burdened women face a higher likelihood of being subjected to sexual harassment at workplace. Therefore, workplaces and violence are saturated sites of intersecting power relations-here, power relations of ableism and sexism. Intersectional subordination is apparent in sexual harassment.

Sexism, ableism, and racism are mutually constructing systems of oppression at the workplace which only accommodate certain bodies ${ }^{99}$. Since they do not allow women like me to feel at home in the workplace, we have to do feminist housework, i.e. challenge the systems of power, social relations, dismantle unequal unjust antifeminist spaces and rebuild the master's residence. ${ }^{100}$ Intersectional feminist theory informs the nature of an accessible workplace - a workplace where women like me fit, we are not questioned, our mobility is not constrained, we are not violated. I want to fit in the chair so that the chair assumes the shape of the body of a disabled woman. I want disability to be the norm and not 'the Other'. 'Feminism [has] made me disabled' by demonstrating to me how positive identity politics can be mobilised for feminist resistance projects, ${ }^{101} \mathrm{such}$ as, this article and/or creating a feminist workplace.

\section{Declaration}

Conflicts of interest The author has no conflicts of interest to declare that are relevant to the content of this article.

Publisher's Note Springer Nature remains neutral with regard to jurisdictional claims in published maps and institutional affiliations.

\footnotetext{
99 See Ahmed, Living a Feminist Life (n 2) 14.

100 Ibid. 2, 7, 14.

101 Garland-Thomson, 'Misfits' (n 6) 603.
} 